Winda Kusumaningrum dan Indah Nurhayati : Penggunaan Karbon Aktif Dari Ampas Tebu Sebagai Media Adsorbsi Untuk Menurunkan Kadar Fe (Besi) dan Mn (Mangan Pada Air Sumur Gali di desa Gelam Candi

\title{
PENGGUNAAN KARBON AKTIF DARI AMPAS TEBU SEBAGAI MEDIA ADSORBSI UNTUK MENURUNKAN KADAR Fe (BESI) DAN Mn (MANGAN) PADA AIR SUMUR GALI DI DESA GELAM CANDI
}

\author{
Winda Kusumaningrum ${ }^{1)}$ dan Indah Nurhayati ${ }^{2)}$ \\ 1) dan 2) Program Studi Teknik Lingkungan; Fakultas Teknik Sipil dan Perencanaan \\ Universitas PGRI Adi Buana Surabaya \\ Email : Winda_kusumaningrum@ymail.com
}

\begin{abstract}
Abstrak
Kandungan besi $(\mathrm{Fe})$ di dalam air sumur dapat menimbulkan gangguan kesehatan, bau kurang enak, menyebabkan warna kuning pada dinding bak kamar mandi serta bercak-bercak kuning pada pakaian. Salah satu cara pengolahan air yaitu dengan teknik adsorbsi menggunakan karbon aktif. Tujuan penelitian ini adalah menentukan konsentrasi $\mathrm{Ca}(\mathrm{OH})_{2}$ yang digunakan untuk membuat karbon aktif dari ampas tebu sebagai media filtrasi untuk menurunkan kadar Fe dan Mn pada air sumur gali desa Gelam kec. Candi, mengkaji efektivitas dua media filter yakni ketebalan media karbon aktif dari ampas tebu setebal $10 \mathrm{~cm}$ dan karbon aktif dari ampas tebu setebal $20 \mathrm{~cm}$. Waktu operasi selama 90 menit dan pengambilan sampel setiap 30 menit. Dari penelitian ini dapat disimpulkan bahwa konsentrasi yang digunakan dalam aktivasi karbon aktif dari ampas tebu adalah dengan konsentrasi $\mathrm{Ca}(\mathrm{OH})_{2}$ 0,00562 M yang telah memenuhi SII 0258-88. Filter yang terbuat dari $P V C$ dengan dengan lebar 4 dim dan ketinggian $100 \mathrm{~cm}$ dengan susunan media karbon aktif $20 \mathrm{~cm}$ dapat menurunkan kandungan Fe dari 5,99 mg/l menjadi 0,36 mg/l dan penurunan kandungan Mn dari $1 \mathrm{mg} / \mathrm{l}$ menjadi $0,36 \mathrm{mg} / \mathrm{l}$ sehingga menghasilkan air bersih yang memenuhi baku mutu sesuai keputusan menteri Kesehatan RI nomor Permenkes RI No 416/Menkes/Per/IX/90. Filtrasi dengan media karbon aktif dari ampas tebu dengan ketebalan $20 \mathrm{~cm}$ mempunyai efisiensi penurunan Fe yaitusebesar 93\% dan Mn sebesar 76\%, dengan waktu operasi 90 menit.
\end{abstract}

Kata kunci : Besi (Fe), Mangan (Mn), Karbon Aktif, Ampas Tebu

\begin{abstract}
The content of iron $(\mathrm{Fe})$ in the well water can cause health problems, unpleasant odor, causing the yellow color of the walls of the bath as well as yellow spots on clothing. One way is by water treatment using activated carbon adsorption technique. The purpose of this study was to determine the concentration of $\mathrm{Ca}(\mathrm{OH}) 2$ which is used to make activated carbon from bagasse as media filtration to reduce levels of $\mathrm{Fe}$ and $\mathrm{Mn}$ in the village dug well water Gelam excl. Candi, examines the effectiveness of the two media filter activated carbon media thickness of $10 \mathrm{~cm}$ bagasse and bagasse activated carbon from $20 \mathrm{~cm}$ thick. Operating time for 90 minutes and sampling every 30 minutes. From this study it can be concluded that the concentrations used in the activation of activated carbon from bagasse is the concentration of $\mathrm{Ca}(\mathrm{OH}) 20.00562 \mathrm{M}$ which has met SII 0258-88. Filters are made of PVC with a width of $4 \mathrm{dim}$ and a height of $100 \mathrm{~cm}$ with activated carbon media arrangement of $20 \mathrm{~cm}$ can lower Fe content of $5.99 \mathrm{mg} / \mathrm{l}$ to $0.36 \mathrm{mg} / \mathrm{l}$ and a decrease in Mn content of $1 \mathrm{mg} / \mathrm{l}$ to 0 , $36 \mathrm{mg} / \mathrm{l}$ to produce clean water that meets quality standards as determined by the minister of Health, the number Permenkes Decree No. 416 / Menkes / Per / IX / 90. Filtration with activated carbon media of bagasse with a thickness of $20 \mathrm{~cm}$ has removal efficiency of $93 \% \mathrm{Fe}$ and $\mathrm{Mn}$ by $76 \%$, with an operating time of 90 minutes.
\end{abstract}

Keywords: Iron (Fe), Manganese (Mn), Activated Carbon, Sugarcane Dregs 


\section{PENDAHULUAN}

Salah satu sumber air bersih yang dimanfaatkan oleh masyarakat adalah air sumur. Kelemahan air sumur adalah banyaknya kandungan logam yang cukup tinggi, karena air sumur mengalami kontak dengan berbagai macam mineral yang ada di bumi. Air sumur biasanya kurang layak digunakan untuk memenuhi kebutuhan hidup manusia misalnya untuk kegiatan rumah tangga, industri, perkantoran, pertanian dan lainnya. Pemenuhan kebutuhan air bersih sebagian besar masyarakat yang ada di pemukiman Desa Gelam, Kecamatan Candi, Kabupaten Sidoarjo dari air sumur gali karena belum meratanya suplay PDAM. Berdasarkan pengamatan pada air sumur di daerah tersebut kualitasnya belum memenuhi baku mutu kebutuhan air bersih menurut PERMENKES No.416/Menkes/Per/IX/1990. Hal ini dapat diketahui dari bak mandi warga yang berwarna kekuning-kuningan, begitu juga apabila dipergunakan untuk mencuci akan memberi noda kekuning-kuningan pada pakaian putih serta berbau seperti besi berkarat. Kualitas air bersih seharusnya sesuai dengan PERMENKES No.416/Menkes/Per/IX/1990 tentang standart kualitas air bersih. Kadar $\mathrm{Fe}$, Mn yang disyaratkan dalam permenkes tersebut masingmasing tidak boleh melebihi dari $1,0 \mathrm{mg} / \mathrm{l}$ untuk Fe, sedangkan Mn 0,5 mg/l 1 (Depkesri, 1990).

Karbon aktif (arang aktif) merupakan suatu padatan berpori yang mengandung 8595\% karbon,dihasilkan dari bahan-bahan yang mengandung karbon dengan pemanasan pada suhu tinggi. Karbon atau arang aktif adalah material yang berbentuk butiran atau bubuk yang berasal dari material yang mengandung karbon misalnya tulang, kayu lunak, sekam, tongkol jagung, tempurung kelapa, sabut kelapa, ampas penggilingan tebu, ampas pembuatan kertas, serbuk gergaji, kayu keras, batubara dan sebagainya.

Menurut Arifin dan Ramli dalam Rahayu (2002), adsorpsi merupakan peristiwa penyerapan suatu zat pada permukaan bahan penyerap, dan yang menjadi dasar untuk proses adsorpsi adalah daya tarik menarik Van Der Waals dan daya tarik menarik elektrostatis Coulomb. Fenomena adsorpsi ini disebabkan oleh :

1. Adanya interaksi antara molekul-molekul komponen dengan permukaan bahan penyerap dimana gaya-gaya Van Der Waals bekerja.

2. Adanya gaya tarik-menarik Coulomb, yang prinsip kerjanya karena adanya perbedaan muatan positf dan negatif.

Kalsium hidroksida termasuk basa kuat karena terionisasi sempurna, akan tetapi basa ini memiliki kelarutan lebih kecil dibandingkan kelarutan $\mathrm{NaOH}$. Agar $\mathrm{Ca}(\mathrm{OH})_{2}$ menjadi lebih efektif dibutuhkan waktu bereaksi yang lebih lama dan dosis yang lebih tinggi. Larutan tersebut bereaksi hebat dengan berbagai asam, dan bereaksi dengan banyak logam dengan adanya air. Larutan tersebut menjadi keruh bila dilewatkan karbon dioksida, karena mengendapnya kalsium karbonat (Keenam,1996).

Besi $(\mathrm{Fe})$ dibutuhkan oleh tubuh dalam pembentukan haemoglobin sehingga jika kekurangan besi (Fe) akan mempengaruhi pembentukan haemoglobin tersebut. Besi $(\mathrm{Fe})$ juga terdapat dalam serum protein yang disebut dengan "transferin" berperan untuk mentransfer besi $(\mathrm{Fe})$ dari jaringan yang satu ke jaringan lain. Besi $(\mathrm{Fe})$ juga berperan dalam aktifitas beberapa enzim seperti sitokrom dan flavo protein. Apabila tubuh tidak mampu mengekskresikan besi (Fe) akan menjadi akumulasi besi $(\mathrm{Fe})$ karenanya warna kulit menjadi hitam. Debu besi (Fe) juga dapat diakumulasi di dalam alveori menyebabkan berkurangnya fungsi paru-paru. Kekurangan besi (Fe) dalam diet akan mengakibatkan defisiensi yaitu kehilangan darah yang berat yang sering terjadi pada penderita tumor saluran pencernaan, lambung dan pada menstruasi. Defisiensi besi (Fe) menimbulkan gejala anemia seperti kelemahan, fatigue, sulit bernafas waktu berolahraga, kepala pusing, diare, penurunan nafsu makan, kulit pucat, kuku berkerut, kasar dan cekung serta terasa dingin pada tangan dan kaki. (Rumapea, 2009 dan Siregar, 2009).

Konsentrasi mangan di dalam sistem air alami umumnya kurang dari $0.1 \mathrm{mg} / \mathrm{l}$, jika konsentrasi melebihi $1 \mathrm{mg} / \mathrm{l}$ maka dengan cara pengolahan biasa sangat sulit untuk menurunkan konsentrasi sampai derajat yang diijinkan sebagai air minum. Oleh karena itu perlu cara pengolahan yang khusus. Pada tahun 1961 WHO menetapkan konsentrasi mangan dalam air minum di Eropa maksimum sebesar $0.1 \mathrm{mg} / \mathrm{l}$, tetapi selanjutnya diperbaharui menjadi $0.05 \mathrm{mg} / \mathrm{L}$. Di Amerika Serikat (U.S. EPA) sejak awal menetapkan konsentrasi 
Winda Kusumaningrum dan Indah Nurhayati : Penggunaan Karbon Aktif Dari Ampas Tebu Sebagai Media Adsorbsi Untuk Menurunkan Kadar Fe (Besi) dan Mn (Mangan Pada Air Sumur Gali di desa Gelam Candi

mangan di dalam air minum maksimum 0.05 $\mathrm{mg} / \mathrm{l}$. Jepang menetapkan total konsentrasi besi dan mangan di dalam air minum maksimum 0.3 $\mathrm{mg} / \mathrm{l}$. Indonesia berdasarkan Keputusan Menteri Kesehatan No. 907 tahun 2002 menetapkan kadar zat besi di dalam air minum maksimum 0.3 dan Mangan maksimum sebesar $0.1 \mathrm{mg} / \mathrm{l}$ (Said, 2003).

Ampas tebu adalah bahan sisa berserat dari batang tebu yang telah mengalami ekstraksi niranya dan banyak mengandung parenkim serta tidak tahan disimpan karena mudah terserang jamur. Serat sisa dan ampas tebu kebanyakan digunakan sebagai bahan bakar untuk menghasilkan energi yang diperlukan untuk pembuatan gula (Slamet, 2004). Menurut Badan peneliti dan pengembangan PT Gula Putih Mataram tahun 2002, ampas tebu mengandung bahan organic sekitar $90 \%$, unsur hara $\mathrm{N}(0,3 \%), \mathrm{P}_{2} \mathrm{O}_{5}(0,02 \%) \mathrm{K}$ (Hardianto, 2010).

Bahan limbah agrikultur yang cukup berpotensial untuk dikembangkan sebagai bahan baku karbon aktif adalah ampas penggilingan tebu, sekam padi, tongkol jagung dan sabut kelapa. Ampas tebu merupakan salah satu bahan yang cukup potensial dikembangkan karena ketersediaannya yang melimpah.. Berdasarkan hasil penelitian sebelumnya arang ampas tebu yang diaktifasi menggunakan $\mathrm{HCl}$ 0,1 M dapat menghasilkan arang aktif yang memenuhi syarat (Asbahani, 2013).

Berdasarkan hasil survei diketahui bahwa sebagian besar pedagang minuman tebu membuang begitu saja ampas tebunya yang dapat mencemari lingkungan. Oleh karena itu, ampas tebu perlu dimanfaatkan salah satunya sebagai adsorben dengan cara pembuatan karbon aktif dengan menggunakan aktivasi $\mathrm{Ca}(\mathrm{OH})_{2}$ yang mudah didapat dan harganya terjangkau diharapkan dapat menjadi nilai tambah serta meningkatkan daya dukungnya terhadap lingkungan. Berdasarakan latar belakang tersebut peneliti ingin melakukan penelitian dengan judul penggunaan karbon aktif dari ampas tebu sebagai media adsorbs untuk menurunkan kadar $\mathrm{Fe}$ dan $\mathrm{Mn}$ pada air sumur gali di Desa Gelam Kecamatan Candi Sidoarjo. Tujuan penelitian adalah menentukan konsentrasi $\mathrm{Ca}(\mathrm{OH})_{2}$ yang paling optimum untuk menghasilkan karbon aktif dengan kualitas sesuai dengan SII 0258-88 dan Mengkaji dan mengetahui pengaruh ketebalan arang aktif ampas tebu sebagai media adsorbsi dalam menurunkan kadar Fe dan Mn dalam air sumur gali di Desa Gelam Kecamatan Candi
Sidoarjo. Manfaat yang didaptkan adalah memberikan informasi kepada masyarakat bahwa ampas tebu dapat digunakan sebagai karbon aktif untuk mengolah air sumur gali yang mengandung besi $(\mathrm{Fe})$ dan mangan $(\mathrm{Mn})$, Sebagai bahan masukan bagi pemerintah dalam mencanangkan program penyediaan dan penyehatan air bersih dan Menambah wawasan penulis dan sebagai bahan referensi bagi peneliti selanjutnya.

\section{METODE}

Populasi dalam penelitian ini adalah air sumur gali di Desa Gelam, Kecamatan Candi, Sidoarjo. Sampel yang digunakan dalam penelitian ini adalah air sumur gali di Perumahan Graha Candi Mas Blok i-38 Desa Gelam Kecamatan Candi.

\section{Variable penelitian}

Variable bebas dalam penelitian ini adalah konsentrasi $\mathrm{Ca}(\mathrm{OH})_{2}$ yang digunakan untuk aktivasi karbon ampas tebu yaitu $0.01125 \mathrm{M}$ dan $0.00562 \mathrm{M}$ dan tingginya karbon aktif sebagai adsorben dalam proses filtrasi yaitu 10 $\mathrm{cm}$ dan $20 \mathrm{~cm}$. Variable terikatnya adalah kualitas karbon aktif menurut SII 0258-88 dan kadar Fe dan Mn dalam air sumur.

\section{Alat dan bahan}

Reaktor filtrasi dari pipa PVC 4 inci dengan panjang $100 \mathrm{~cm}$, tandon air, pompa, furnance, oven, peralatan gelas untuk analisis Fe dan Mn, spektrofotometer, $\mathrm{Ca}(\mathrm{OH})_{2}$, ampas tebu, kerikil, pasir silica.

\section{Langkah-langkah Penelitian}

1. Karbonisasi ampas tebu

Ampas tebu dikeringkan dengan matahari langsung hingga kadar air yang dikandung rendah (kering). Kemudian ampas tebu dipotong-potong dengan ukuran $5 \mathrm{~mm}$. Ampas tebu dibakar dalam furnance selama 30 menit pada suhu $300^{\circ} \mathrm{C}$.

2. Aktivasi karbon

Karbon direndam menggunakan $\mathrm{Ca}(\mathrm{OH})_{2}$ dengan konsentrasi yang di variasikan yaitu $0.01125 \mathrm{M}$ dan $0.00562 \mathrm{M}$ ) selama 4 jam pada suhu suhu $80{ }^{\circ} \mathrm{C}$. Perendaman dilanjutkan dengan suhu kamar selama 24 jam. Karbon disaring dengan kertas saring, dan dicuci dengan aquadest hingga $\mathrm{pH} 7$. Karbon dikeringkan dalam oven dari suhu kamar sampai suhu $150^{\circ} \mathrm{C}$ selama 2 jam. 
Winda Kusumaningrum dan Indah Nurhayati : Penggunaan Karbon Aktif Dari Ampas Tebu Sebagai Media Adsorbsi Untuk Menurunkan Kadar Fe (Besi) dan Mn (Mangan Pada Air Sumur Gali di desa Gelam Candi

3. Uji kualitas karbon aktif menurut SII 025888

a. Analisis bagian yang hilang pada pemanasan $950^{\circ} \mathrm{C}$

Karbon aktif dipanaskan sampai suhu $950^{\circ} \mathrm{C}$ dalam furnace. Setelah suhu tercapai, karbon dibiarkan dingin dalam furnace dalam kondisi tidak berhubungan dengan udara luar. Setelah dingin dimasukkan ke dalam desikator dan ditimbang.

Rumus :

Volatile matter $(\%)=\frac{a-b}{a} \times 100 \%$

$a=$ berat karbon aktif mula-mula (gram)

$\mathrm{b}=$ berat karbon akhir

b. Uji Kadar Air (SII)

Karbon aktif ditimbang seberat 1 gram dan dimasukkan ke dalam krus p orselin yang telah dikeringkan, kemudian dimasukkan ke dalam oven pada suhu $115^{\circ} \mathrm{C}$ selama 3 jam, selanjutnya sampel karbon aktif didinginkan dalam desikator dan ditimbang. Kadar air dapat dihitung dengan persamaan berikut:

Volatile matter $(\%)=\frac{\mathrm{a}-\mathrm{b}}{\mathrm{b}} \times 100 \%$

$\mathrm{a}=$ berat karbon aktif mula- mula (gram)

$\mathrm{b}=$ berat karbon aktif setelah dikeringkan (gram)

c. Uji Daya Serap terhadap Iodium (SII)

1. Karbon aktif ditimbang sebanyak 0,5 gram dan dicampurkan dengan $50 \mathrm{ml}$ larutan Iodium $0,1 \mathrm{~N}$, kemudian dikocok dengan alat pengocok selama 15 menit.

2. Setelah itu sampel disentrifuge sampai karbonnya turun.

3. Kemudian diambil $10 \mathrm{ml}$ larutan sampel dan dititrasi dengan larutan Natrium Tiosulfat $0,1 \mathrm{~N}$.

4. Jika warna kuning pada larutan mulai samar, ke dalam larutan tersebut ditambahkan larutan amilum $1 \%$ sebagai indikator sehingga berwarna biru tua.

5. Larutan dititrasi kembali sampai warna biru tua berubah menjadi warna bening.

$\mathrm{I}_{2}(\mathrm{mg} / \mathrm{g})=\frac{\frac{1-\mathrm{V} \times \mathrm{N}}{0.1} \times 1,6 \times 5}{\mathrm{~W}}$
$\mathrm{V}=$ volume natrium thio sulfat

$\mathrm{N}=$ normalitas atrium thiosulfat

$12,69=\mathrm{jml} \mathrm{I}_{2}$ sesuai dengan $1 \mathrm{ml}$ natrium thiosulfat

$\mathrm{W}=$ berat sampel

d. Uji Kadar Abu

Karbon aktif yang ditimbang seberat 1 gram dimasukkan ke dalam kurs porselin yang telah diketahui beratnya. Lalu diabukan dalam furnace secara perlahan setelah semua karbon hilang.

Nyala diperbesar pada suhu $800^{\circ} \mathrm{C}$ selama 2 jam. Bila seluruh karbon telah menjadi abu, dinginkan dalam desikator lalu ditimbang hingga diperoleh bobot tetapnya.

Rumus :

Kadar $\mathrm{abu}=\frac{\mathrm{b} \quad \mathrm{a}}{\mathrm{b} \quad \mathrm{s} \hat{\imath}} \times 100 \%$

4. Karbon aktif ampas tebu dengan kualitas terbaik digunakan untuk media filtrasi.

a. Memasukan media ke dalam rekator filtrasi

b. Air dipompakan ke tandon atas

c. Kran dari tandon atas dibuka hingga air memenuhi bak pengatur debit.

d. Air dari bak pengatur debit masuk ke kedua filter.

e. Membiarkan air keluar beberapa saat ( lebih kurang 5 - 10 menit) hingga aliran stabil.

f. Menghitung debit pada kran outlet kedua filter.

g. Mengambil sampel air sebelum diolah dari outlet bak pengatur debit.

h. Mengambil sampel tiap 30 menit selama 90 menit

\section{Metode Analisis Data}

Data hasil penelitian disajikan dalam bentuk tabel dan grafik dengan menggunakan metode prosentase dari penurunan kadar $\mathrm{Fe}$ dan $\mathrm{Mn}$ sampel sesudah melewati filter I dan filter II

\section{HASIL DAN PEMBAHASAN}

\section{Uji Kualitas Karbon Aktif dari Ampas Tebu}

Arang yang dihasilkan dari suhu karbonisasi $300^{\circ} \mathrm{C}$ memiliki sifat fisika dan kimia yang berbeda pula. Hasil pengujian sifat fisika dan kimia arang yang dihasilkan dari karbonisasi ampas tebu disajikan pada Tabel 1. 
Winda Kusumaningrum dan Indah Nurhayati : Penggunaan Karbon Aktif Dari Ampas Tebu Sebagai Media Adsorbsi Untuk Menurunkan Kadar Fe (Besi) dan Mn (Mangan Pada Air Sumur Gali di desa Gelam Candi

Tabel 1. Sifat Fisika dan Kimia Arang Ampas Tebu berdasarkan SII 0258-88

\begin{tabular}{|c|c|c|c|c|}
\hline \multirow{2}{*}{ KUALITAS ARANG } & \multicolumn{2}{|c|}{$\mathrm{Ca}(\mathrm{OH})_{2}$} & \multirow{2}{*}{$\begin{array}{c}\text { SII/ } \\
\text { padatan }\end{array}$} & \multirow{2}{*}{ Keterangan } \\
\hline & $0.01125 \mathrm{M}$ & $0,00562 M$ & & \\
\hline $\begin{array}{l}\text { Bagian yang hilang pada } \\
\text { pemanasam } 950^{\circ} \mathrm{C}(\%)\end{array}$ & 3.3 & 4.6 & Maks. 25 & $\begin{array}{l}\text { Memenuhi } \\
\text { syarat }\end{array}$ \\
\hline $\begin{array}{c}\text { Kadar air (oven } 115 \\
\text { derajat, } 3 \text { jam) (\%) }\end{array}$ & 23 & 24 & Maks. 15 & $\begin{array}{c}\text { Tidak } \\
\text { Memenuhi } \\
\text { syarat }\end{array}$ \\
\hline $\begin{array}{c}\text { uji kadar abu (furnance } \\
\left.850^{\circ} \mathrm{C}\right)(\%)\end{array}$ & 0 & 0 & Maks. 10 & $\begin{array}{l}\text { Memenuhi } \\
\text { syarat }\end{array}$ \\
\hline Daya serap $\mathrm{I}_{2} \mathrm{mg} / \mathrm{g}$ & 279 & 381 & Min. 75 & $\begin{array}{l}\text { Memenuhi } \\
\text { syarat }\end{array}$ \\
\hline
\end{tabular}

Berdasarkan Tabel 1. uji kualitas karbon aktif dari ampas tebu, dapat disimpulkan bahwa karbon aktif dengan konsentrasi $\mathrm{Ca}(\mathrm{OH})_{2} 0,00562 \mathrm{M}$ dan konsentrasi $\mathrm{Ca}(\mathrm{OH})_{2}$ $0.01125 \mathrm{M}$ kedua nya memenuhi standart kualitas SII-0258-88. Namun jika dilihat dari daya serap iodium $\left(\mathrm{I}_{2}\right)$ konsentrasi $0,00562 \mathrm{M}$ lebih tinggi daripada konsentrasi yang 0.01125 M yaitu $381 \mathrm{mg} / \mathrm{g}$. Hal ini karena tingginya kadar karbon tersebut menunjukkan bahwa fraksi karbon yang terikat di dalam arang semakin tinggi. Kondisi tersebut mengakibatkan luas permukaan arang semakin besar dan jumlah pori arang semakin banyak, sehingga mempunyai kemampuan menyerap cairan atau gas yang lebih tinggi. Oleh karena itu media filtrasi yang digunakan dalam penelitian ini adalah karbon aktif dari ampas tebu dengan pembakaran selama $300^{\circ} \mathrm{C}$ selama setengah jam dan di aktifasi dengan $\mathrm{Ca}(\mathrm{OH})_{2}$ konsentrasi $0,00562 \mathrm{M}$ selama 4 jam dengan suhu $80^{\circ} \mathrm{C}$

Pengaruh Ketebalan Media Karbon Aktif Ampas Tebu terhadap Penurunan Fe dan Mn

Pengaruh ketebalan media karbon aktif ampas tebu terhadap penurunan $\mathrm{Fe}$ dan $\mathrm{Mn}$ dapat di lihat pada tabel 2 berikut ini:

Tabel 2. Kandungan Fe dan Mn Setelah melalui Filtrasi

\begin{tabular}{|c|c|c|c|c|c|c|c|}
\hline \multirow{2}{*}{ Filter } & \multirow{2}{*}{ Parameter } & \multicolumn{4}{|c|}{ Menit } & \multirow{2}{*}{ Baku Mutu } & \multirow{2}{*}{ Satuar } \\
\hline & & 0 & 30 & 60 & 90 & & \\
\hline \multirow{2}{*}{$\mathrm{F} 1$} & $\mathrm{Fe}$ & 6.35 & 1.35 & 1.51 & 1.42 & 1 & $\mathrm{mg} / \mathrm{l}$ \\
\hline & $\mathrm{Mn}$ & 1.36 & 0.68 & 0.61 & 0.52 & 0.5 & $\mathrm{mg} / \mathrm{l}$ \\
\hline \multirow{2}{*}{ F2 } & $\mathrm{Fe}$ & 6.35 & 0.45 & 0.3 & 0.36 & 1 & $\mathrm{mg} / \mathrm{l}$ \\
\hline & Mn & 1.36 & 0.41 & 0.32 & 0.36 & 0.5 & $\mathrm{mg} / \mathrm{l}$ \\
\hline
\end{tabular}

Ket : F1 : Filtrasi 1

F2 : Filtrasi 2

Dari tabel 2. dapat dilihat bahwa F1 dengan media karbon aktif dari ampas tebu setebal $10 \mathrm{~cm}$ dengan waktu operasi 90 menit dapat menurunkan kandungan $\mathrm{Fe}$ sebesar 4,93 $\mathrm{mg} / \mathrm{l}$ dan $\mathrm{Mn}$ sebesar 0,84 mg/l. Berdasarkan hasil di atas kandungan Fe dan Mn di F1 sudah mengalami penurunan kandungan, namun air bersih yang di hasilkan belum memenuhi baku mutu Standard Permenkes RI No 416/Menkes/Per/IX/90.

F2 dengan media karbon aktif dari ampas tebu setebal $20 \mathrm{~cm}$ dengan waktu operasi 90 menit dapat menurunkan kandungan Fe sebesar 5,99 $\mathrm{mg} / \mathrm{l}$ dan Mn sebesar $1 \mathrm{mg} / \mathrm{l}$. Berdasarkan hasil di atas kandungan Fe dan Mn di F1 mengalami penurunan kandungan dan air bersih yang di hasilkan telah memenuhi baku mutu Standard Permenkes RI No 416/Menkes/Per/IX/90.

\section{Efisiensi Penurunan Fe dan Mn}

Berikut efisiensi penurunan kandungan $\mathrm{Fe}$ dan Mn pada sumur gali dapat dilihat di tabel 3 berikut ini : 
Winda Kusumaningrum dan Indah Nurhayati : Penggunaan Karbon Aktif Dari Ampas Tebu Sebagai Media Adsorbsi Untuk Menurunkan Kadar Fe (Besi) dan Mn (Mangan Pada Air Sumur Gali di desa Gelam Candi

Tabel 3. Efisiensi Kandungan Fe dan Mn Setelah melalui Filtrasi

\begin{tabular}{ccccc}
\hline \multirow{2}{*}{ Filter } & \multirow{2}{*}{ Parameter } & \multicolumn{3}{c}{ Menit } \\
\cline { 3 - 5 } & & $\mathbf{3 0}$ & $\mathbf{6 0}$ & $\mathbf{9 0}$ \\
\hline \multirow{2}{*}{ FI } & $\mathrm{Fe}$ & $79 \%$ & $76 \%$ & $78 \%$ \\
& $\mathrm{Mn}$ & $50 \%$ & $55 \%$ & $62 \%$ \\
\multirow{2}{*}{ F2 } & $\mathrm{Fe}$ & $93 \%$ & $95 \%$ & $94 \%$ \\
& $\mathrm{Mn}$ & $70 \%$ & $76 \%$ & $74 \%$ \\
\hline
\end{tabular}

\section{Ket : F1 : Filtrasi 1}

F2 : Filtrasi 2

Prosentase penurunan $\mathrm{Fe}$ dan $\mathrm{Mn}$ oleh karbon aktif dari ampas tebu dengan ketebalan media $10 \mathrm{~cm}$ mencapai rata-rata $77,53 \%$ dan Mn mencapai 55,64\% turun hingga 4,93 mg/l untuk Fe dan Untuk Mn 0,84 mg/ 1. Sedangakan untuk ketebalan $20 \mathrm{~cm}$ mencapai rata-rata 94,17\% dan Mn mencapai 73,28\% turun hingga $5,99 \mathrm{mg} / \mathrm{l}$ untuk Fe dan Untuk Mn $1 \mathrm{mg} / 1$.
Sehingga ketebalan ampas tebu dengan tinggi media $20 \mathrm{~cm}$ memiliki kecenderungan dalam mengadsorbsi kadar Fe dan Mn, semakin tinggi media semakin luas zona adsorbsi. Gambar 1 dan gambar 2 merupakan pengaruh ketebal media karbon aktif ampas tebu terhadap efisiensi penurunan Fe dan Mn.

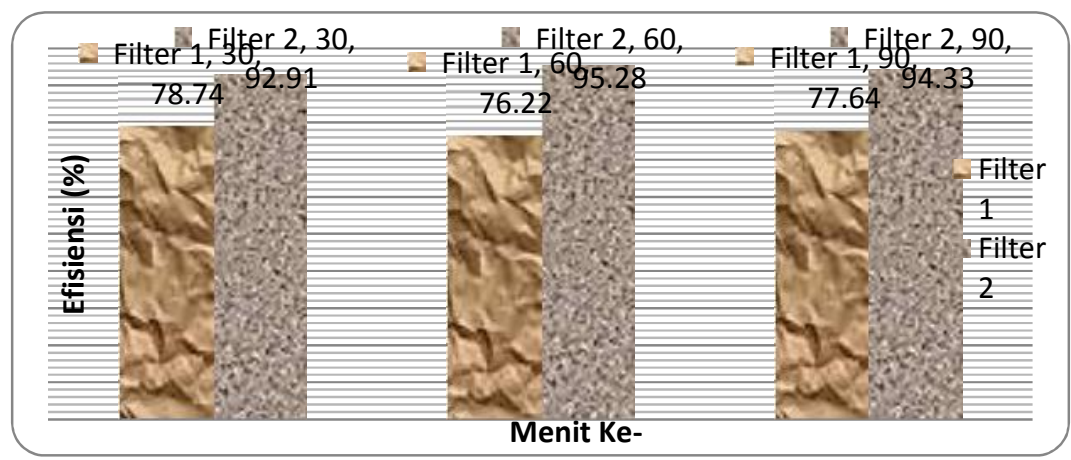

Gambar 1. Grafik Efisiensi Penurunan Fe pada filter 1 dan 2

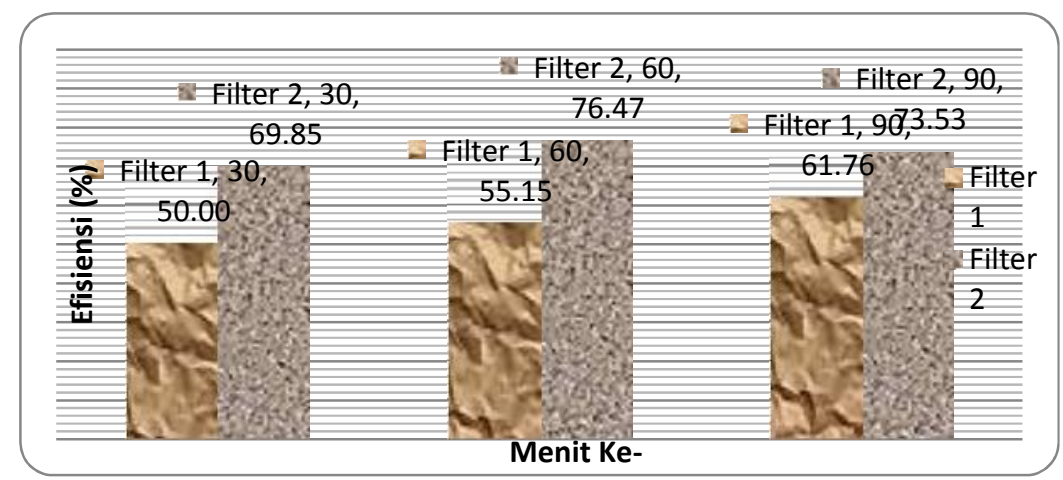

Gambar 2. Grafik Efisiensi Penurunan Mn pada filter 1 dan 2

Dari gambar 1 dan 2 dapat dilihat Filter 2 dengan tebal karbon aktif lebih tinggi ternyata mempunyai efisiensi penurunan $\mathrm{Fe}$ dan $\mathrm{Mn}$ yang lebih baik dari F1 yang media karbon aktifnya lebih sedikit hal ini karena semakin banyak media yang di tambahkan, maka semakin luas permukaan pori-pori yang dapat menampung masuknya $\mathrm{Fe}$ dan $\mathrm{Mn}$, Dengan semakin banyak yang dapat tertampung maka kadar Fe dan Mn semakin berkurang. 
Winda Kusumaningrum dan Indah Nurhayati : Penggunaan Karbon Aktif Dari Ampas Tebu Sebagai Media Adsorbsi Untuk Menurunkan Kadar Fe (Besi) dan Mn (Mangan Pada Air Sumur Gali di desa Gelam Candi

\section{KESIMPULAN}

Berdasarkan hasil penelitian dapat disimpulkan bahwa

1. Konsentrasi aktivasi $\mathrm{Ca}\left(\mathrm{OH}_{2} 20,00562 \mathrm{M}\right.$ merupakan konsentrasi yang paling optimum untuk digunakan media adsorbsi karena memiliki daya serap $\mathrm{I}_{2}$ yang tinggi dibanding konsentrasi $\mathrm{Ca}(\mathrm{OH})_{2} 0,01125 \mathrm{M}$.

2. Filtrasi dengan media karbon aktif dengan ketebalan $20 \mathrm{~cm}$ mempunyai efisiensi penurunan $\mathrm{Fe}$ yaitusebesar $93 \%$ dan $\mathrm{Mn}$ sebesar $76 \%$, dengan waktu operasi 90 menit.

Untuk meningkatkan hasil penelitian maka,

1. Perlu diadakan penelitian lebih lanjut tentang pembuatan arang ampas tebu pada tingkat variabel suhu yang lebih tinggi untuk melihat apakah dengan suhu yang semakin tinggi akan semakin meningkatkan kualitas arang tersebut.

2. Perlu dilakukan penelitian lanjutan tentang ukuran media yang optimum dalam menurunkan Fe dan Mn dan lamanya waktu kontak yang efektif dari masing-masing media hingga mencapai titik jenuh

3. Dari hasil penurunan $\mathrm{Fe}$ dan $\mathrm{Mn}$ yang belum memenuhi persyaratan yang berlaku maka perlu dilakukan penelitian lebih lanjut mengenai ketebalan optimum dari masingmasing media.

\section{UCAPAN TERIMA KASIH}

Ucapan terima kasih ditujukan kepada laboratorium Teknik Lingkungan Universitas PGRI Adi Buana (UNIPA) Surabaya sebagai tempat penelitian dan analisis sampel.

\section{DAFTAR PUSTAKA}

Asbahani . 2013. Pemanfaatan Limbah Ampas Tebu Sebagai Karbon Aktif Untuk Menurunkan Kadar Besi Pada Air Sumur Jurnal Teknik Sipil Untan / Volume 13 Nomor 1 - Juni 2013

Departemen Kesehatan berdasarkan Peraturan Menteri Kesehatan Republik Indonesia Nomor : 416/MENKES/PER/IX/1990 tahun 1990 tentang Syarat-syarat dan Pengawasan Kualitas Air Bersih.

Hardianto, dan Wulandari, Candra Dwiratna, 2010. Penggunaan Aktifator Dalam pengomposan Aerobik Ampas Tebu Prosiding Seminar Nasional Teknologi Ramah Lingkunga Dalam Pembangunan Berkelanjutan. ITN Malang, 15 Juli 2010

Keenan, 1996, Kimia Untuk Universits, Erlangga, Jakarta

Parulian, Alwin. 2009. Monitoring dan Analisis Kadar Aluminium (Al) dan Besi (Fe) Pada Pengolahan Air Minum PDAM Tirtanadi Sunggal.Medan : Pascasarjana - Universitas Sumatera Utara (USU).

Rahayu. 2002. Studi Perbandingan Pengolahan Limbah Industri Tekstil Antara yang Menggunakan Metode Flotasi dan yang Menggunakan Metode Adsorpsi Karbon Aktif. Universitas Terbuka. Lembaga Penelitian Pusat Studi Indonesia.

Rumapea, Nurmida. 2009. Penggunaan Kitosan dan Polyaluminium Chlorida (PAC) Untuk Menurunkan Kadar Logam Besi (Fe) dan Seng (Zn) Dalam Air Gambut. Medan : Pascasarjana - USU

Said, Nusa Idaman. 2003. Metoda Praktis penghilangan Zat besi dan Mangan Di Dalam Air Minum. Jakarta : Kelair - BPPT

Siregar, M. 2009. Pengaruh Berat Molekul Kitosan Nanopartikel Untuk Menurunkan Kadar Logam Besi (Fe) dan Zat Warna Pada Limbah Industri Tekstil Jeans. Medan : Pascasarjana Universitas Sumatera Utara. 